\title{
Host Tissue Response To Foreign Body
}

National Cancer Institute

\section{Source}

National Cancer Institute. Host Tissue Response To Foreign Body. NCI Thesaurus. Code C50586.

Growth of tissue in or around a foreign body as the body's antibody response to the foreign body. 